Article

\title{
Seasonal and Event-Based Hydrological and Slope Stability Modeling of Pyroclastic Fall Deposits Covering Slopes in Campania (Southern Italy)
}

\author{
Pantaleone De Vita * (D), Francesco Fusco ${ }^{\mathbb{D}}$, Rita Tufano and Delia Cusano \\ Dipartimento di Scienze della Terra, dell'Ambiente e delle Risorse (DiSTAR), University of Naples Federico II, \\ Complesso Universitario di Monte Sant'Angelo, Via Cinthia, Edificio L1, 80126 Naples, Italy; \\ francesco.fusco@unina.it (F.F.); rita.tufano@unina.it (R.T.); deliacusano@libero.it (D.C.) \\ * Correspondence: padevita@unina.it; Tel.: +39-081-253-5069
}

Received: 26 July 2018; Accepted: 20 August 2018; Published: 25 August 2018

check for updates

\begin{abstract}
The pyroclastic fall deposits mantling mountain slopes in the Campania region (Southern Italy) represent one of the most studied geomorphological frameworks of the world regarding rainfall-induced debris flows threating urban areas. The proposed study focused on advancing knowledge about the hydrological response of pyroclastic fall coverings from the seasonal to event-based time scales, leading to the initiation of slope instability. The study was based on two consequential tasks. The first was the analysis of a six-year monitoring of soil pressure head carried out in a sample area of the Sarno Mountains, located above a debris flow initiation zone. The second was based on coupled hydrological and slope stability modeling performed on the physical models of slopes, which were reconstructed by empirical correlations between the slope angle, total thickness, and stratigraphic settings of pyroclastic fall deposits mantling slopes. The results obtained were: (a) The understanding of a soil pressure head regime of the volcaniclastic soil mantle, always ranging in unsaturated conditions and characterized by a strong seasonal variability depending on precipitation patterns and the life cycle of deciduous chestnut forest; and (b) the reconstruction through a deterministic approach of seasonal intensity-duration rainfall thresholds related to different morphological conditions.
\end{abstract}

Keywords: pyroclastic fall deposits; soil hydrological monitoring; slope hydrological response; debris flows hazard; physically based modeling; rainfall thresholds

\section{Introduction}

Understanding the hydrological processes occurring in soil mantled slopes that lead to the triggering of rapid flow-like shallow landslides is becoming even more of a principal task for researchers focused on coping with landslide hazards in urbanized areas and developing effective mitigation strategies based on early warning systems [1]. In such a context, it is possible to estimate the rainfall thresholds that lead to shallow landslides being triggered [2] by using approaches based on the empirical analysis of landslide event inventories and the corresponding rainfall conditions $[3,4]$, which can be affected by relevant uncertainties due to the incompleteness of the inventories themselves, the unrepresentativeness of rainfall measurements, and unknown antecedent hydrological conditions [5]. Therefore, in recent years, the goal of many researchers has been the comprehension of hillslope hydrological processes leading to shallow landslide triggering by soil hydrological monitoring and modeling approaches [6]. In several cases, the outcomes of such studies have been used for the estimation of threshold hydrological conditions (e.g., rainfall intensity vs. duration or soil pressure head) by coupling them with slope stability modeling $[7,8]$. 
This paper deals with a special case of landslide hydrology study related to rainfall-triggered debris flows that recurrently affect pyroclastic fall deposits covering the slopes of mountains and hills nearby the volcanic centers of the Campania region (Southern Italy). Such shallow landslides have been intensely studied in the last two decades due to the high-risk conditions suffered by urbanized areas at the footslopes of these mountains [9]. The severity of these types of geohazards is clearly remarked by the high loss of life, amounting to about 600 in the 20th century and a life loss probability that strongly exceeds any conventional As Low as Reasonably Practicable (ALARP) landslide risk level $[10,11]$. In this regard, among the deadliest debris flow events, those of the highest magnitude occurred on the Amalfi Coast in Italy (Lattari Mountains) in October 1954 with 316 victims, and in the Sarno Mountains in May 1998 with 160 victims that deserve to be mentioned.

This landslide hydrology study was considered to be special as it related to landslides involving allochthonous soils derived from the air-fall deposition of volcanic ashes instead of the more common case of autochthonous soils, produced by the weathering of bedrock and in situ development of a regolith zone [12-14]. Besides their particular stratigraphic setting, hydrological and geotechnical properties, pyroclastic fall coverings also differ from other types of autochthonous soil mantles in their spatial distribution, which is controlled by the magnitude and orientation of dispersal axes of volcanic eruptions as well as denudational processes acting along the slopes. Moreover, these volcaniclastic soil coverings play a very relevant hydrological role by strictly controlling the location and timing of debris flow initiation due to their unsaturated and saturated hydrological properties, Mediterranean climate conditions with rainy winters and dry summers, and dense deciduous vegetation cover, which exerts a fluctuating evapotranspiration demand $[15,16]$.

In this paper, the results of the hydrological characterization of representative landslide initiation areas of the Sarno and Lattari Mountains based on the recognition of stratigraphic settings of the pyroclastic fall soil mantle, characterization of unsaturated, and saturated hydrological properties of volcanic ashes, and soil hydrological monitoring are shown comprehensively. Based on this, the seasonal intensity-duration rainfall thresholds [3] were estimated by physically-based models through joint hydrological and slope stability analyses, which were applied to the most hazardous morphological conditions of the Sarno and Lattari Mountains (Figure 1).

\section{Study Area and Landslide Phenomena Description}

The study was based on the hydrological monitoring of a pyroclastic fall soil covering at a representative test site, whose results were used to estimate the I-D rainfall thresholds for the Sarno and Lattari Mountains. The latter, together with the Avella and Salerno Mountains, are constituted of a Mesozoic carbonate platform series bordering the Campanian Plain, at whose middle the Somma-Vesuvius and Phlegrean Fields volcanoes are located (Figure 1). During the Miocene, these series were faulted and thrusted by compressive tectonic phases forming the Apennines orogeny [17-19]. By the Quaternary extensional tectonic phases, these units were affected by normal faulting that led to their tectonic lowering along the Tyrrhenian border and the formation of a semi-graben where back-arc volcanic activity began, first forming the Phlegrean Fields (39 ky BP) and the Somma-Vesuvius volcano (25 ky BP). The pyroclastic flow and fall deposits erupted by these volcanic centers also filled the structural depression with alluvial deposits, thus forming the current Campanian Plain. In particular, the pyroclastic fall deposits mantled the peri-volcanic areas that included the nearby mountain ranges with thickness and stratigraphic settings depending on the magnitude and direction of the dispersal axes of the principal eruptions, which vary from 9 to $4 \mathrm{~m}$ for the Sarno Mountains and from 1 to $3 \mathrm{~m}$ for the Lattari Mountains (Figure 1).

In the Sarno Mountains, a complete stratigraphic setting can be found in areas with negligible denudational processes that were formed by alternating unweathered volcaniclastic soils and paleosols horizons that developed between consecutive eruptions. By means of a composite approach based on pedological [20], lithological, and engineering soil classifications (USCS), the volcaniclastic series can be described as formed, from the top, by an alternation of weathered and pedogenized fine and coarse 
pumiceous ashes, corresponding to the $\mathrm{A}$ and $\mathrm{B}$ horizons (top soil) and $\mathrm{Bb}$ horizons (both classified as SM), and levels formed by scarcely weathered pumiceous gravels ranging from coarse ashes to lapilli [21] in grain size (GW and GP) that were related to deposits of different eruptions [22-24]. At the bottom of the volcaniclastic series, a basal paleosol ( $\mathrm{Bb}_{\text {basal }}$ horizon) (SM) casing the carbonate bedrock and filling open discontinuities of the carbonate rock mass has always been observed. In contrast, for the Lattari Mountains, the volcaniclastic series, besides the shallower A and B soil horizons, is chiefly characterized by a single $C$ soil horizon related to the A.D. 79 Pompeii eruption [25], while a second thin C horizon, corresponding to scoriaceous lapilli of the 1944 eruption [26] was observed only in limited areas. Even in the case of the Sarno Mountains, a basal paleosol ( $\mathrm{Bb}_{\text {basal }}$ horizon) was also always recognized as covering the bedrock and filling its irregularities.

These rainfall-induced shallow landslides have very rapid kinematics and complex mechanisms [27-29] characterized by three evolutionary stages with varying rheological behaviors: (1) Initial debris slide (soil slip), generally of small volume (in the order of few tens of cubic meters); (2) debris avalanche [29], mobilizing other pyroclastic material along the slope by a dynamic liquefaction mechanism and remarkably increasing the landslide volume; and (3) debris flow [29], occurring if the preceding debris avalanche is channeled in the hydrographic network. In this case, the landslide entrains material along its path, increasing its volume. Assuming these mechanisms, the landslide hydrological study focused on the initial debris slide stage, which can be considered as the trigger for subsequent evolutionary stages [30].

Interestingly, throughout the initiation zones of the initial debris slides, the $\mathrm{Bb}_{\text {basal }}$ horizon has always recognized outcropping, thus revealing the formation of the initial rupture surface within the pyroclastic fall soil covering and allowing the exclusion of the role of groundwater outflow from the carbonate bedrock, as it has been supposed in other geotechnical models [31,32].

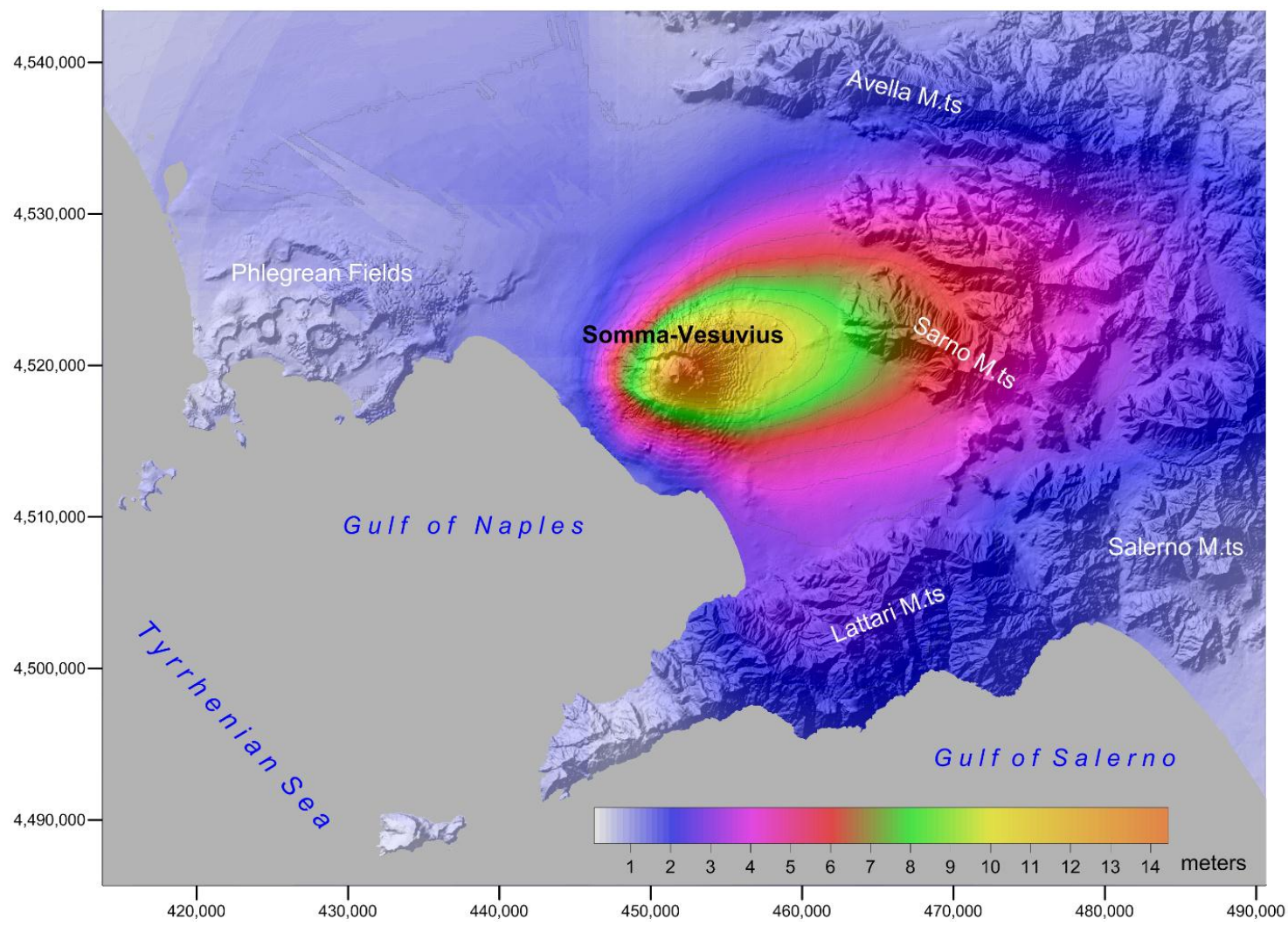

Figure 1. Distribution of the pyroclastic fall deposits reconstructed for the peri-volcanic areas surrounding the Campanian Plain based on the deposit thicknesses of the principal eruptions of the Phlegrean Fields and Somma-Vesuvius volcanoes, modified from [33]. 


\section{Spatial Distribution of Pyroclastic Fall Deposits}

In addition to the original inhomogeneous distribution of pyroclastic fall deposits in the peri-volcanic areas, which depends on the eruption magnitude and orientation of the dispersal axes, these allochthonous soil coverings have been recognized with strong spatially variable thicknesses along the mountain slopes of the Avella, Lattari, and Sarno Mountains that also depend on the intensity of the local denudational processes [34]. Based on consistent field surveys carried out along the slopes of the Sarno and Lattari Mountains, a good match between the field measurements and expected values estimated by the algebraic sum of isopach maps of principal eruptions of the Phlegrean Fields and Somma-Vesuvius volcanoes (Figure 1), was found for conservative geomorphological conditions, generally corresponding to a slope angle value lower than about $30^{\circ}$ (Figure 2). Instead, for greater slope angle values, a rapid and steady decrease of volcaniclastic soil mantle thickness was recognized until it reached the negligibility or total lack above slope angle of about 50 [33-35] (Figure 2). These observations were understood as geomorphological indicators of a substantial slope stability for the slope angle range below $30^{\circ}$ and a landslide susceptibility condition for greater values, up to $50^{\circ}$, above which the absence of the pyroclastic fall deposits prevented landslides. Moreover, a diminishing thickness of the volcaniclastic soil mantle for slope angles greater than about $30^{\circ}$, observed as having a strong control on the stratigraphic settings $[33,36]$ leading to the downslope pinching out of the $\mathrm{C}$ and $\mathrm{Bb}$ soil horizons up to the direct contact of the $\mathrm{B}$ horizon on the $\mathrm{Bb}_{\text {basal }}$ one, was found for slope angle values between $42^{\circ}$ and $45^{\circ}$ (Figure 2), determining a hydrological discontinuity along the downslope direction that could lead locally to a condition favorable to the increase of pore pressure during heavy rainfall events and then to a higher susceptibility to debris flow initiation [37]. 


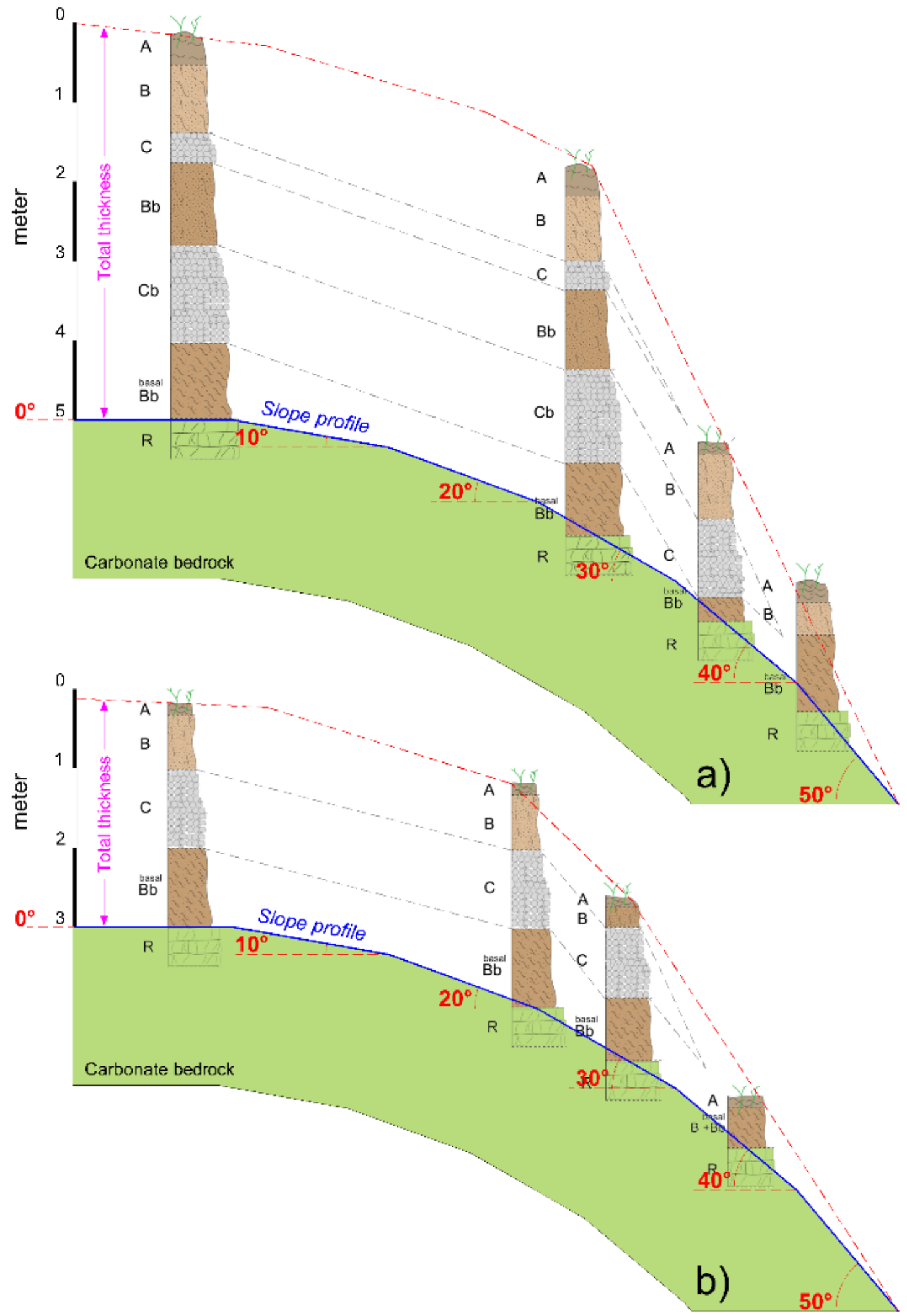

Figure 2. Empirical distribution model of pyroclastic fall soil thicknesses and stratigraphic settings depending on the slope angle for the Sarno (a) and Lattari (b) Mountains. In the slope angle range lower than $30^{\circ}$, the total thicknesses and stratigraphic settings well matched with those expected. Instead, for greater slope angle values, an abrupt decrease of total thicknesses and change of stratigraphic settings were observed up to the disappearance of the volcaniclastic soil cover for slope angle values greater than about $50^{\circ}$. 
According to the abovementioned observations, assessing the spatial variability of pyroclastic fall deposit thickness and their stratigraphic settings along mountain slopes can be considered a key factor for understanding the hydrological processes leading to slope instability under certain hydrological conditions. Basically, the thickness of the pyroclastic fall soil cover regulates the amount of capillary water stored into the soil profile, then the antecedent hydrological status, which controls slope instability, or stability, under a certain rainfall event [38].

\section{Data and Methods}

To assess the hydrological response of pyroclastic fall soil mantled slopes, a soil hydrological monitoring station was installed at a test site located along the southwestern slope of the Pizzo D'Alvano Mt., $1.133 \mathrm{~m}$ a.s.l., in the Sarno Mountains (Figure 1). The monitoring activity spanned across the period between December 2010 and December 2016.

Moreover, to assess the hydrological conditions controlling the onset of initial debris slides, intensity-duration rainfall thresholds [2,3] were estimated by deterministic approaches based on coupled hydrological and slope stability modeling of slope physical models related to different morphological conditions. The latter were reconstructed for the Sarno and Lattari Mountains through physical models based on the empirical relationships between the pyroclastic fall soil thickness, stratigraphic settings, and slope angle.

\subsection{Soil Hydrological Monitoring}

The soil hydrological monitoring station was installed upslope of a debris flow source area chosen as representative among the several tens that occurred in May 1998 in the Sarno Mountains. This test site was also considered as representative of the typical thickness of pyroclastic fall deposits, reaching a maximum value of $4.5 \mathrm{~m}$, stratigraphic setting, morphological features, and vegetation cover existing in the source areas of debris flows along the mountains and hills surrounding the volcanic centers of the Campania region. Starting from the landslide main scarp and moving upslope, the site is shaped with a regular profile and a mean slope angle of about $32^{\circ}$. Instead, downslope of the main scarp, the pyroclastic fall soil cover pinches out at the top of a vertical carbonate rocky scarp that is about $5.0 \mathrm{~m}$ high. The vegetation in the sample area is a chestnut (Castanea sativa) deciduous forest with sparse evergreen brushwood.

Upslope of the landslide scar and in alignment with the slope direction line, $23 \mathrm{~m}$ in length, six light dynamic penetrometer tests and three exploratory pits were carried out to reconstruct the stratigraphic settings and related correlations. Furthermore, undisturbed soil samples were taken for each soil horizon by exploratory pits. Soil samples were tested using standard laboratory procedures consisting of soil identification tests (USCS), shear strength characterization, and the assessment of unsaturated/saturated soil properties $[39,40]$. Considering the results of both the field surveys and laboratory tests, an engineering geological model of the monitoring station area was created (Figure 3). The layout of the monitoring station was specifically designed for measuring the soil pressure head selectively in each volcaniclastic soil horizon. Tensiometers (Soilmoisture Inc.) were used for monitoring the soil pressure head range above about $-8.0 \mathrm{~m}$ at sea level, while Watermark sensors (Irrometer, Riverside, CA) were installed to measure soil pressure head values lower than about $-8.0 \mathrm{~m}$ at sea level, down to $-20.4 \mathrm{~m}$. Finally, after considering first the monitoring results, which indicated in summer the occurrence of soil pressure head values lower than the functioning limit of Watermark sensors ( $-20.4 \mathrm{~m}$ ), MPS-2 sensors (Decagon technologies) with a functioning limit at about $-1000.0 \mathrm{~m}$ were also installed in the test area in June 2015. 


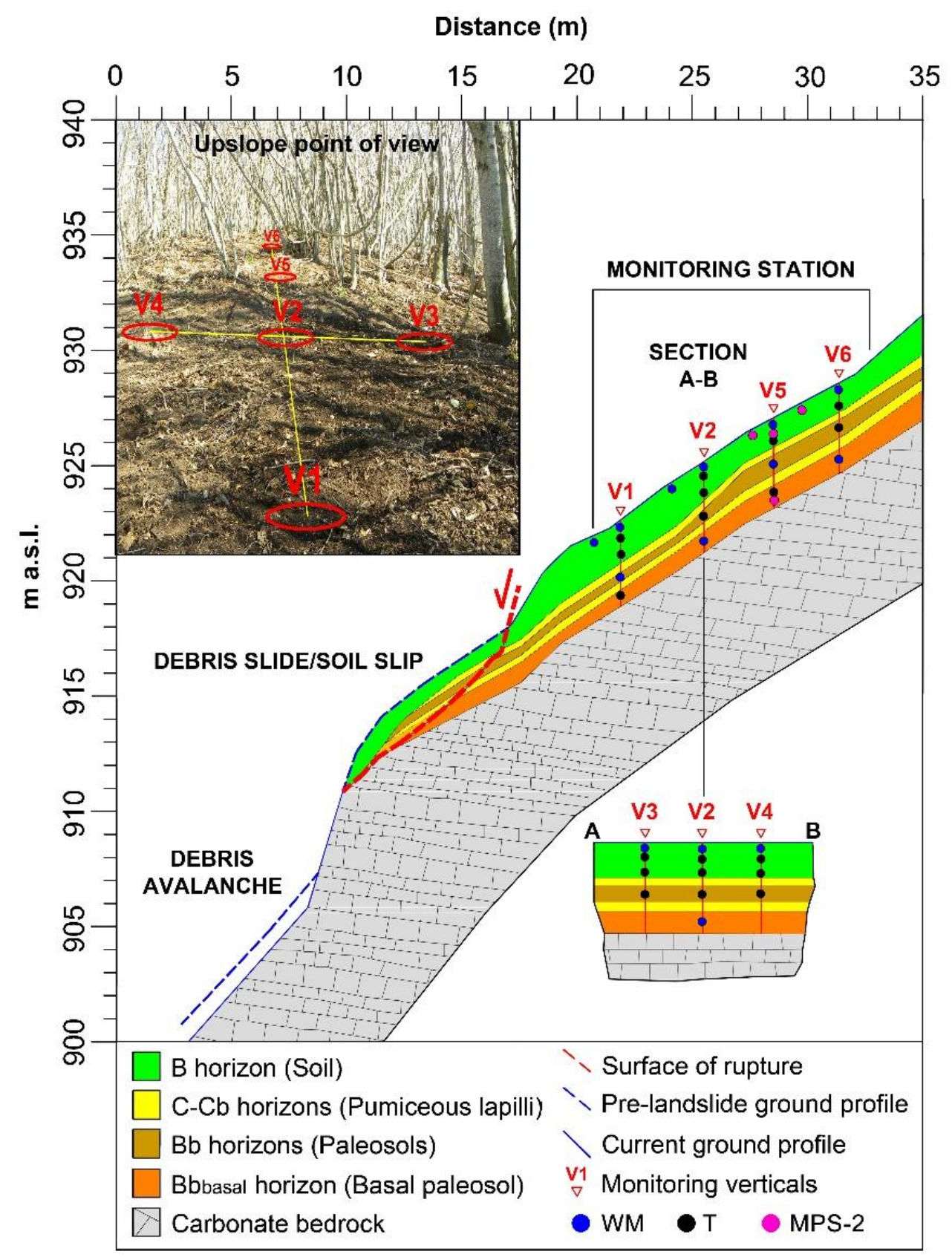

Figure 3. Graphical plan of monitoring verticals (V1-V6) and location of the tensiometers (T), Watermark (WM) and MPS-2 sensors in the test-site geological model. The upper-left box shows an upslope view of one of the monitoring sites, modified from [38].

The larger part of the sensors was deployed in the B soil horizon, considering it is characterized by a more enhanced hydrological response to rainfall events and the evapotranspiration process. The other sensors were distributed with a lower number in the $\mathrm{Bb}$ and $\mathrm{Bb}$ basal horizons (Table 1 ), while no sensors were installed in the $C$ soil horizon due to its coarse grain size, which inhibited a reliable hydraulic contact between the soil and sensors. 
Table 1. Type and number of sensors installed in the pyroclastic fall soil horizons (except for the C horizon), and range depth.

\begin{tabular}{ccccc}
\hline Horizon & Tensiometer & Watermark & MPS-2 & Range Depth (m) \\
\hline $\mathrm{B}$ & 16 & 8 & 3 & $0.0-1.5$ \\
$\mathrm{Bb}$ & 5 & 2 & 1 & $1.8-2.5$ \\
$\mathrm{Bb}_{\text {basal }}$ & 2 & 2 & 1 & $3.5-4.0$ \\
\hline
\end{tabular}

Sensors were arranged in six verticals aligned to two straight transects, respectively, corresponding and normal to the slope direction line. The one parallel to the slope direction line, comprising four verticals (V1, V2, V5, and V6), was set from the landslide crown and stretched upslope for about $10.0 \mathrm{~m}$. The second was formed by the alignment of two additional verticals (V3 and V4) that crossed the first transect at the $\mathrm{V} 2$ vertical with a reciprocal distance of about $5.0 \mathrm{~m}$ from the V2 (Figure 3). The measuring rate was regulated at $10 \mathrm{~min}$ for sensors provided with automatic dataloggers, and weekly for tensiometers not provided with a datalogger. The soil pressure head time series was homogenized at the daily time scale by a respective downscaling through the calculation of the average daily value, and upscaling, by a linear variation between two consecutive readings.

Moreover, daily rainfall and air temperature data were collected by recordings of a meteorological station managed by the Civil Protection Department in the nearby Torriello locality (\#ID rain-gauge 15.285), sited at a distance less than $1 \mathrm{~km}$.

The analyses of soil pressure head regime were carried out considering the rainfall and evapotranspiration patterns as well as the life seasonal cycle of the deciduous chestnut forest, which is characterized by a strong evapotranspiration demand during spring and summer due to the development of the leaf coverage, and a low one during the dormant period of autumn and winter. Moreover, to analyze the seasonal hydrological response of the pyroclastic fall soil cover, the frequency of the pressure head time series was analyzed by the reconstruction of duration curves (DCs) [41]. This approach was considered relevant for estimating the temporal probability (hazard) of the assumed antecedent hydrological conditions of the volcaniclastic soil mantle that can favor, or prevent, the initiation of debris flows under a single rainfall event with given intensity and duration values.

\subsection{Coupled Hydrological and Slope Stability Modeling}

On the basis of the empirical relationships between the thickness and slope angle, the physical, hydrological, and slope stability modeling of pyroclastic fall soil mantle was carried out in the area of the Sarno and Lattari Mountains [33,34]. In particular, the physical modeling, based on the empirical relationships between the slope angle and maximum total thicknesses of the volcaniclastic mantle and single soil horizons, found the same slope angle interval in the field surveys carried out in the Sarno and Lattari areas [42,43]. Through these empirical models, three representative stratigraphic settings related to the slope angle values of $35^{\circ}, 40^{\circ}$, and $45^{\circ}$ were modeled for both the Sarno and Lattari Mountains (Figure 4), which were chosen to include the slope angle range where the debris flows of May 1998 initiated more than 75\% of cases [44]. 


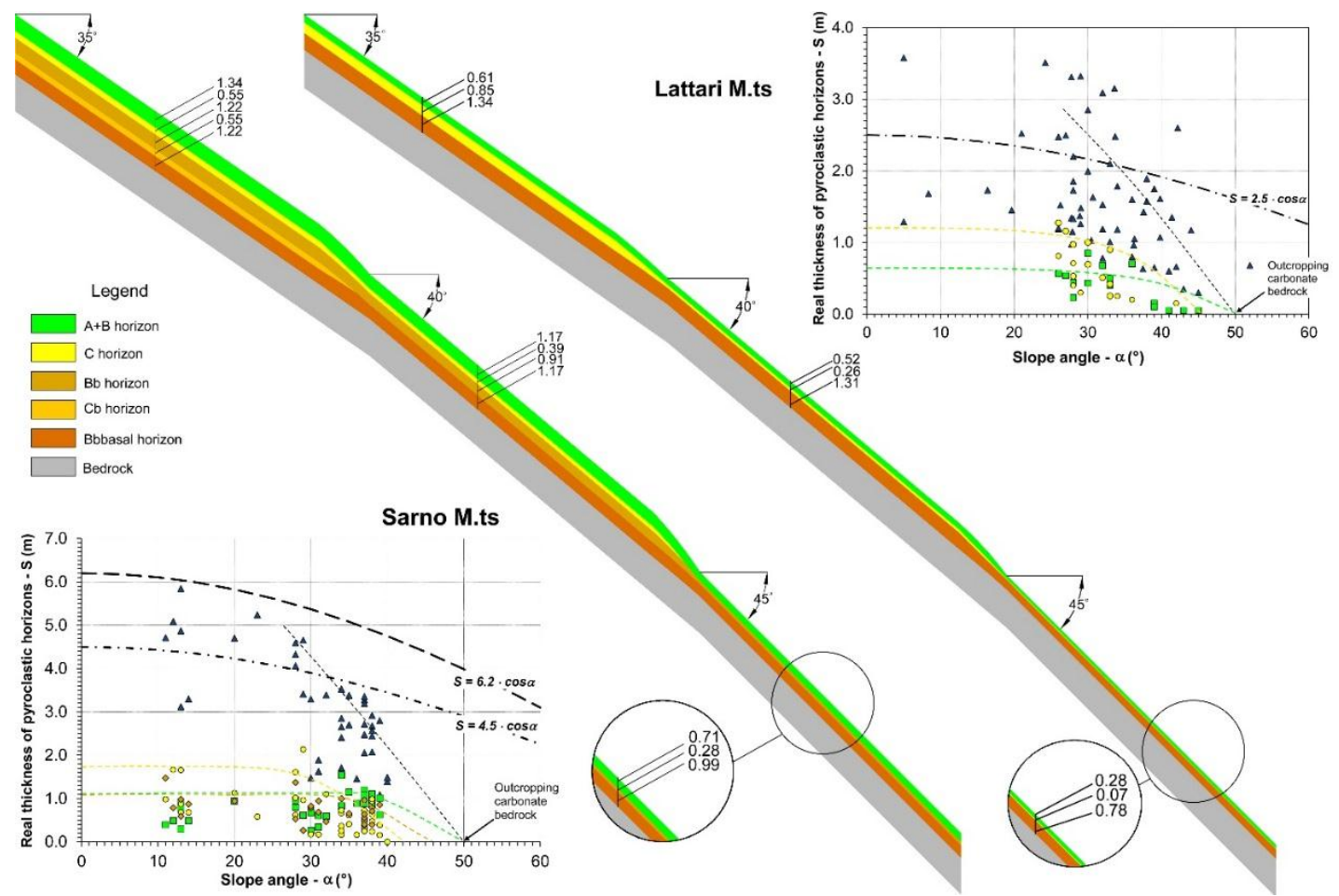

Figure 4. Physical slope models of the Sarno and Lattari Mountains, reconstructed for slope angle values of $35^{\circ}, 40^{\circ}$, and $45^{\circ}$ by empirical relationships (see charts in the opposite corners) between the thicknesses of the whole pyroclastic fall soil mantle (blue triangles) and single soil horizons (dots in other colors).

In particular, for the Sarno Mountains, physical slope models of $35^{\circ}, 40^{\circ}$, and $45^{\circ}$ were reconstructed with a progressive diminishing thickness of the volcaniclastic mantle and variable stratigraphic settings depicted as follows: two $\mathrm{C}$ horizons were considered for the $35^{\circ}$ slope model instead just one for the slope model at $40^{\circ}$, and none for the $45^{\circ}$ case. Instead, for the Lattari Mountains, a stratigraphic setting with a single $C$ horizon was considered for the slope models of $35^{\circ}, 40^{\circ}$, and $45^{\circ}$ (Figure 4).

The physical slope models were implemented in the VS2DTI finite-difference numerical code [45] for modeling slope hydrological response under a rainfall event of a given constant intensity and considering antecedent hydrological conditions, as assumed to be representative for winter and summer seasons by the recorded soil pressure head time series. The modeling was carried out by considering the upper and bottom boundary conditions corresponding to a vertical flux for simulating infiltration process and gravity drainage to the carbonate bedrock, respectively. Moreover, rainfall events were considered with a constant intensity of $2.5,5,10,20$, to $40 \mathrm{~mm} / \mathrm{h}$. The model was run in transient conditions and set with a time step of $600 \mathrm{~s}$. To set the representative physically-based models, the hydro-mechanical properties of the volcaniclastic soil horizons, obtained by field and laboratory tests by previous studies [39], were considered (Tables 2 and 3). 
Table 2. Unsaturated hydraulic and mechanical parameters considered for the VS2DTI hydrological modeling [39].

\begin{tabular}{cccccc}
\hline Parameter & Horizon B & Horizon Bb & Horizon Bb $_{\text {basal }}$ & Horizon C & Bedrock \\
\hline$\gamma_{\text {dry }}\left(\mathrm{kN} / \mathrm{m}^{3}\right)$ & 10.22 & 10.33 & 6.83 & 8.42 & - \\
$\gamma_{\text {nat }}\left(\mathrm{kN} / \mathrm{m}^{3}\right)$ & 12.09 & 11.64 & 10.09 & 10.57 & - \\
$\gamma_{\mathrm{sat}}\left(\mathrm{kN} / \mathrm{m}^{3}\right)$ & 15.85 & 16.16 & 13.82 & 14.94 & - \\
$\mathrm{c}^{\prime}(\mathrm{kPa})$ & 4.3 & 0.7 & 8.1 & 0.2 & - \\
$\phi^{\prime}\left({ }^{\circ}\right)$ & 31.5 & 33.5 & 35.1 & 37.0 & - \\
$\theta \mathrm{s}[-]$ & 0.500 & 0.560 & 0.590 & 0.630 & 0.030 \\
$\theta \mathrm{r}[-]$ & 0.080 & 0.200 & 0.001 & 0.001 & 0.020 \\
$\alpha\left[\mathrm{m}^{-1}\right]$ & 5.600 & 0.730 & 7.200 & 4.200 & 4.310 \\
$\mathrm{n}[-]$ & 1.570 & 1.320 & 1.110 & 1.430 & 3.100 \\
\hline
\end{tabular}

Table 3. Range of saturated hydraulic conductivity $\left(\mathrm{K}_{\text {sat }}\right)$ between percentiles of $25 \%$ and $75 \%$ determined for each ash-fall pyroclastic soil horizon [39].

\begin{tabular}{ccc}
\hline Soil Horizon (USDA) & Percentile $\mathbf{2 5 \%}<\mathbf{K}_{\text {sat }}<$ Percentile $\mathbf{7 5 \%} \mathbf{( m / s )}$ & Number of Samples \\
\hline $\mathrm{B}$ & $4.82 \times 10^{-5}<\mathrm{K}_{\text {sat }}<1.26 \times 10^{-4}$ & 18 \\
$\mathrm{Bb}$ & $6.00 \times 10^{-6}<\mathrm{K}_{\text {sat }}<2.64 \times 10^{-5}$ & 13 \\
$\mathrm{Bb}_{\text {basal }}$ & $2.48 \times 10^{-7}<\mathrm{K}_{\text {sat }}<6.84 \times 10^{-6}$ & 15 \\
$\mathrm{C}$ & $2.82 \times 10^{-3}<\mathrm{K}_{\text {sat }}<1.26 \times 10^{-2}$ & 29 \\
\hline
\end{tabular}

The soil pressure head and water content time series, calculated by the VS2DTI code for each time step, were obtained for several observation points located at diverse depths and vertically aligned in different sectors of the slope models. These modeling outcomes were used for carrying out infinite slope stability analyses for each slope model. In detail, a variable unit weight of volcaniclastic soil horizons, depending on water content, was considered. Shear strength forces were set by also considering the contributions of the apparent cohesion, according to the soil suction stress model [46]. Moreover, considering the approximate perpendicularity of the main scarp to the orientation of driving forces, the tensile shear strength acting along it was also taken into account. By these calculations, the factor of safety (FoS) was estimated for rainfall events with constant rainfall intensity $(2.5,5,10,20$, and $40 \mathrm{~mm} / \mathrm{h}$ ) and variable duration to identify the critical duration of rainfall events leading to slope instability $(\mathrm{FoS}=1)$.

\section{Results}

\subsection{Hydrological Response of the Pyroclastic Fall Soil Mantle}

The hydrological monitoring of the pyroclastic fall soil mantle in the test area allowed us to record the soil pressure head time series for six years (December 2010-December 2016) and for each soil horizon, except for C (Figure 5). In the period preceding the installation of MPS-2 sensors, the pressure head time series presented several interruptions of recordings, from a few days to a few weeks, due to exceeding the functioning limits of the tensiometers and Watermark sensors or by the damage produced by wild boars (for limited periods). However, the different functioning limit and the great number of installed sensors allowed a quite continuous monitoring of the soil pressure head. 


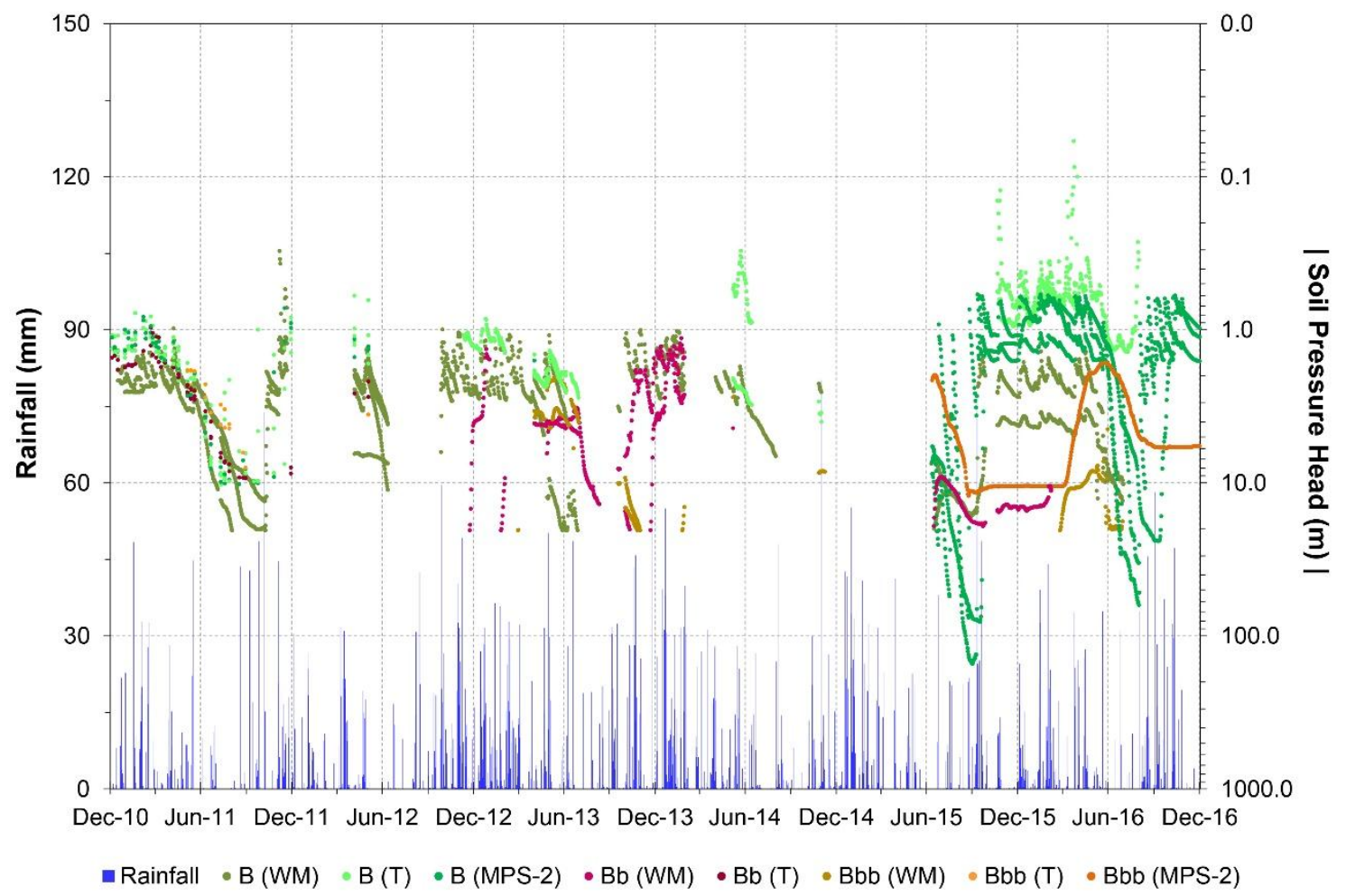

Figure 5. Absolute value of the pressure head time series recorded for the $\mathrm{B}, \mathrm{Bb}$, and $\mathrm{Bb}_{\text {basal }}$ soil horizons in the period December 2010-December 2016. Data are shown according to the soil horizon and type of sensor: (T) tensiometer; (WM) Watermark sensor; (MPS-2) Decagon's MPS-2 sensors. The histogram represents the daily rainfall data.

Overall, the pressure head time series results were constantly limited to unsaturated conditions and were remarkably influenced by seasonality as it appeared to be directly controlled by rainfall and evapotranspiration regimes. Near saturation conditions with pressure head values close to $-0.5 \mathrm{~m}$ were recognized only after heavier rainfall events in the shallowest soil horizons, even if the saturation was never reached.

The whole soil pressure head time series was investigated by a basic descriptive statistical approach to estimate the maximum, median, and minimum values that occurred in each soil horizon (Table 4). From the latter and other statistical analyses, the soil pressure head values recorded by the MPS-2 sensor were excluded because they covered only a limited part of the time series (June 2015-December 2016). 
Table 4. Descriptive statistics of soil pressure head data recorded for the whole pyroclastic fall soil mantle (Whole cover) and single soil horizon (except for C) during the monitoring period 2011-2016.

\begin{tabular}{cccccccc}
\hline Soil horizon & $\mathbf{2 0 1 1}$ & $\mathbf{2 0 1 2}$ & $\mathbf{2 0 1 3}$ & $\mathbf{2 0 1 4}$ & $\mathbf{2 0 1 5}$ & $\mathbf{2 0 1 6}$ & \\
\hline B & -0.3 & -0.6 & -0.8 & -0.3 & -0.1 & -0.1 & \\
Bb & -1.0 & -2.2 & -1.3 & -1.1 & -9.2 & -10.4 & Max \\
Bb bas $_{\text {b }}$ & -1.8 & -3.6 & -2.0 & -2.8 & -2.0 & -1.6 & \\
Whole cover & -0.3 & -0.6 & -0.8 & -0.3 & -0.1 & -0.1 & \\
B & -2.2 & -1.6 & -2.2 & -2.4 & -4.0 & -1.0 & \\
Bb & -2.5 & -2.7 & -4.5 & -2.5 & -14.7 & -14.2 & Median \\
Bb & -3.2 & -3.6 & -4.2 & -8.4 & -10.5 & -5.9 & \\
Whole cover & -2.3 & -2.1 & -3.4 & -2.5 & -7.6 & -5.8 & \\
B & $<-20.4$ & -11.1 & $<-20.4$ & -6.7 & -152.2 & -62.8 & \\
Bb & -9.3 & -20.4 & $<-20.4$ & -4.4 & -19.2 & -15.1 & Min \\
Bb bas & -8.0 & -3.6 & $<-20.4$ & $<-20.4$ & -12.2 & $<-20.4$ & \\
Whole cover $_{\text {bhan }}$ & $<-20.4$ & -20.4 & $<-20.4$ & $<-20.4$ & -152.2 & -62.8 & \\
\hline
\end{tabular}

Considering the subdivision of the hydrological year in a rainy period, typically occurring from November to April, and a dry one, characteristically going on from May to October, further remarks concerning the seasonal control were carried out. During the rainy periods, higher soil pressure head values were observed as controlled by greater rainfall amounts and lower evapotranspiration rates within a range limited to above the functioning limit of the Watermark sensors $(-20.4 \mathrm{~m})$. In these periods, the time series showed a number of soil pressure head spikes well matched the rainfall events. Among all the soil horizons, the shallower B horizon showed the greatest fluctuations in soil pressure head values and a temporal correlation between the soil pressure head and rainfall events, more direct than those found for the other deeper soil horizons ( $\mathrm{Bb}$ and $\left.\mathrm{Bb}_{\text {basal }}\right)$.

At the beginning of the spring, a steady decreasing trend of soil pressure head was identified for all six hydrological years and associated with the soil water loss due to the activity stage of the deciduous chestnut forest, the increased evapotranspiration demand as well as the rarefaction of rainfall events. In these periods, the soil pressure head values fluctuated between -0.7 and $-152.2 \mathrm{~m}$ with an appreciable matching of peaks with the timing of rainfall events, particularly for the first $0.20-0.30 \mathrm{~m}$ of depth.

In the dry periods, soil pressure head was measured down to the functioning limit of the Watermark sensors $(-20.4 \mathrm{~m})$ and did not record the values exceeding it. In this period, only after the installation of the MPS-2 sensors, the pressure head was measured in the B soil horizon and observed to reach a minimum value of $-152.2 \mathrm{~m}$ (Figure 5). Then, starting from the beginning of autumn, a rising trend was determined by rainfall events, mostly rainstorms, and the end of the deciduous forest activity. This condition was observed going on first and more markedly in the shallower soil B horizon, then involving the deeper $\mathrm{Bb}$ and $\mathrm{Bb}_{\text {basal }}$ ones with a delayed timing.

Through the seasonal duration curves (DCs) of the soil pressure head time series, three main frequency classes were identified for the whole volcaniclastic soil cover: the first one ranging between $-0.5 \mathrm{~m}$ and $-4.0 \mathrm{~m}$; the second between $-4.0 \mathrm{~m}$ and $-20.4 \mathrm{~m}$ (functioning limit of the Watermark sensors); and the third related to values exceeding this lower limit and not recorded. In detail, the first class was found with seasonal exceedance percentiles of about $40 \%$ in autumn, $74 \%$ in winter, $84 \%$ in spring, and $40 \%$ in summer (Figure 6). 

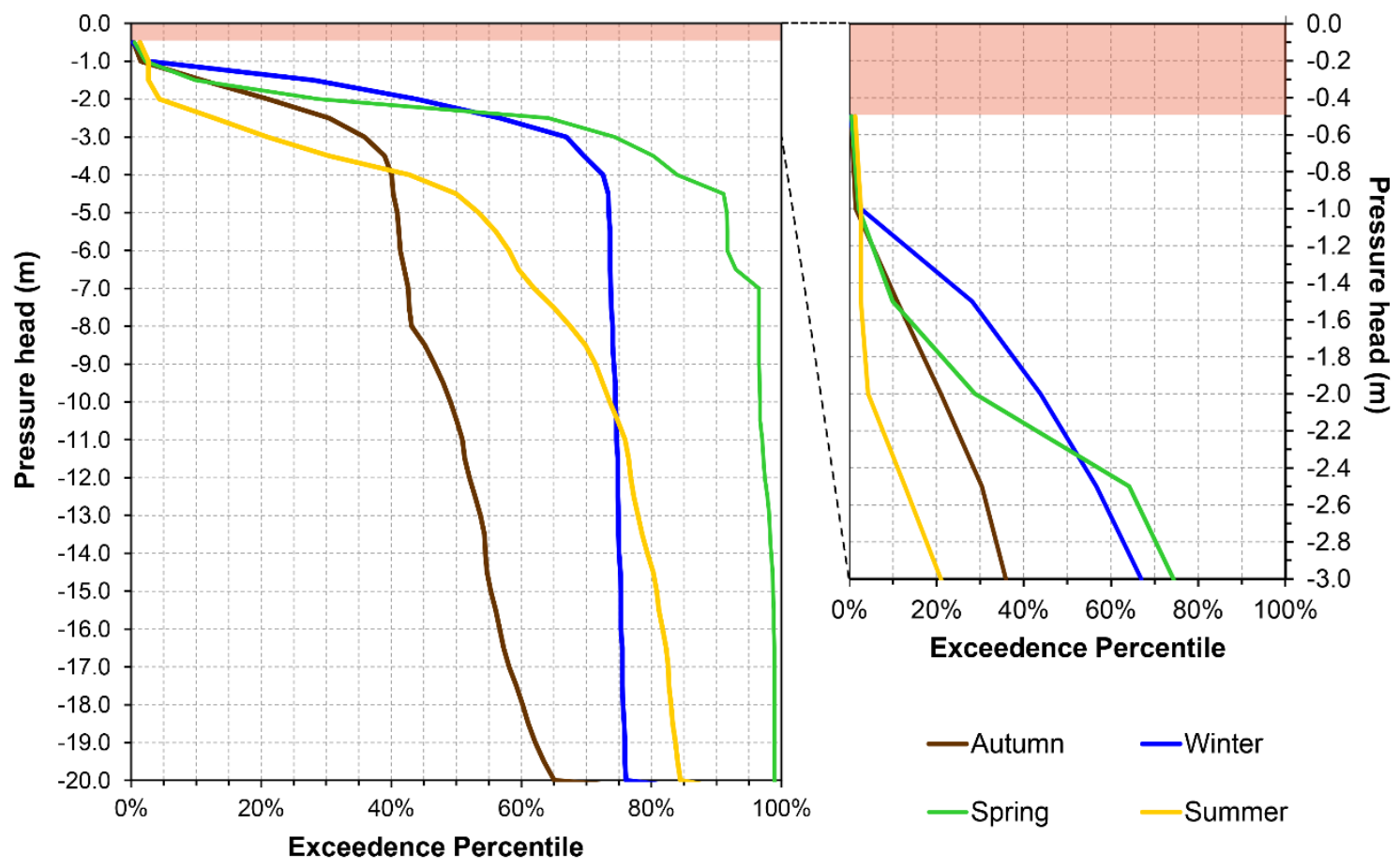

Figure 6. Seasonal duration curves (DCs) of the soil pressure head for the entire pyroclastic fall soil mantle, modified from [38]. Pressure head values lower than $-0.5 \mathrm{~m}$ (red zone) were never observed.

Moreover, the seasonal DCs of the single soil horizon allowed us to understand the dynamics occurring within the pyroclastic fall soil mantle among different soil horizons (Figure 7).

During autumn, considering the knee point along the DCs of the $\mathrm{B}$ and $\mathrm{Bb}$ soil horizons, corresponding to the pressure head value of $-3.0 \mathrm{~m}$, approximately equal to the mean field capacity, the exceedance percentiles of $60 \%$ and $12 \%$ could be recognized, which indicated a condition for the $\mathrm{B}$ horizon as wetter than the deeper $\mathrm{Bb}$ and $\mathrm{Bb}_{\text {basal }}$ ones (Figure $7 \mathrm{a}$ ). Therefore, an inhomogeneous hydrological condition of the volcaniclastic soil mantle was identified by characterizing the ash-fall pyroclastic soil cover during autumn.

In winter, the DCs of soil pressure head showed the same knee point at $-3.0 \mathrm{~m}$ and the corresponding exceedance percentiles of $96 \%$ and $46 \%$, respectively, thus indicating an advance of the wetting process for these soil horizons (Figure $7 \mathrm{~b}$ ). Instead, for the $\mathrm{Bb}_{\text {basal }}$ soil horizon, the soil pressure head values were lower than $-14 \mathrm{~m}$, indicating an unexpected further progress of the drying process. Through the analysis of the DCs, an opposite wetting of the shallower $\mathrm{B}$ and $\mathrm{Bb}$ soil horizons and drying of the $\mathrm{Bb}_{\text {basal }}$ soil horizon was recognized, testifying to the decoupled hydrological response of the entire volcaniclastic soil mantle between shallower and deeper horizons. During spring, the analysis of the DCs showed knee points at $-3.0 \mathrm{~m}$ for the B horizon and at $-4.0 \mathrm{~m}$ for the $\mathrm{Bb}$ and $\mathrm{Bb}_{\text {basal }}$ soil horizons with related exceedance percentiles of $88 \%, 95 \%$, and $88 \%$, respectively. Therefore, a more homogeneous hydrological condition for the whole pyroclastic fall soil cover was recognized during spring, even if this indicated the beginning of the drying process for the shallower B soil horizon and the progress of the wetting one for deeper soil horizons (Figure 7c). Finally, in summer, the analysis of the $\mathrm{DC}$ s showed the knee points for the $\mathrm{B}, \mathrm{Bb}$, and $\mathrm{Bb}_{\text {basal }}$ soil horizons corresponding to the soil pressure head values of $-5.0 \mathrm{~m}$ with related exceedance percentiles of $52 \%, 44 \%$, and $86 \%$, respectively, thus indicating the drying process decreased with depth (Figure 7d). 

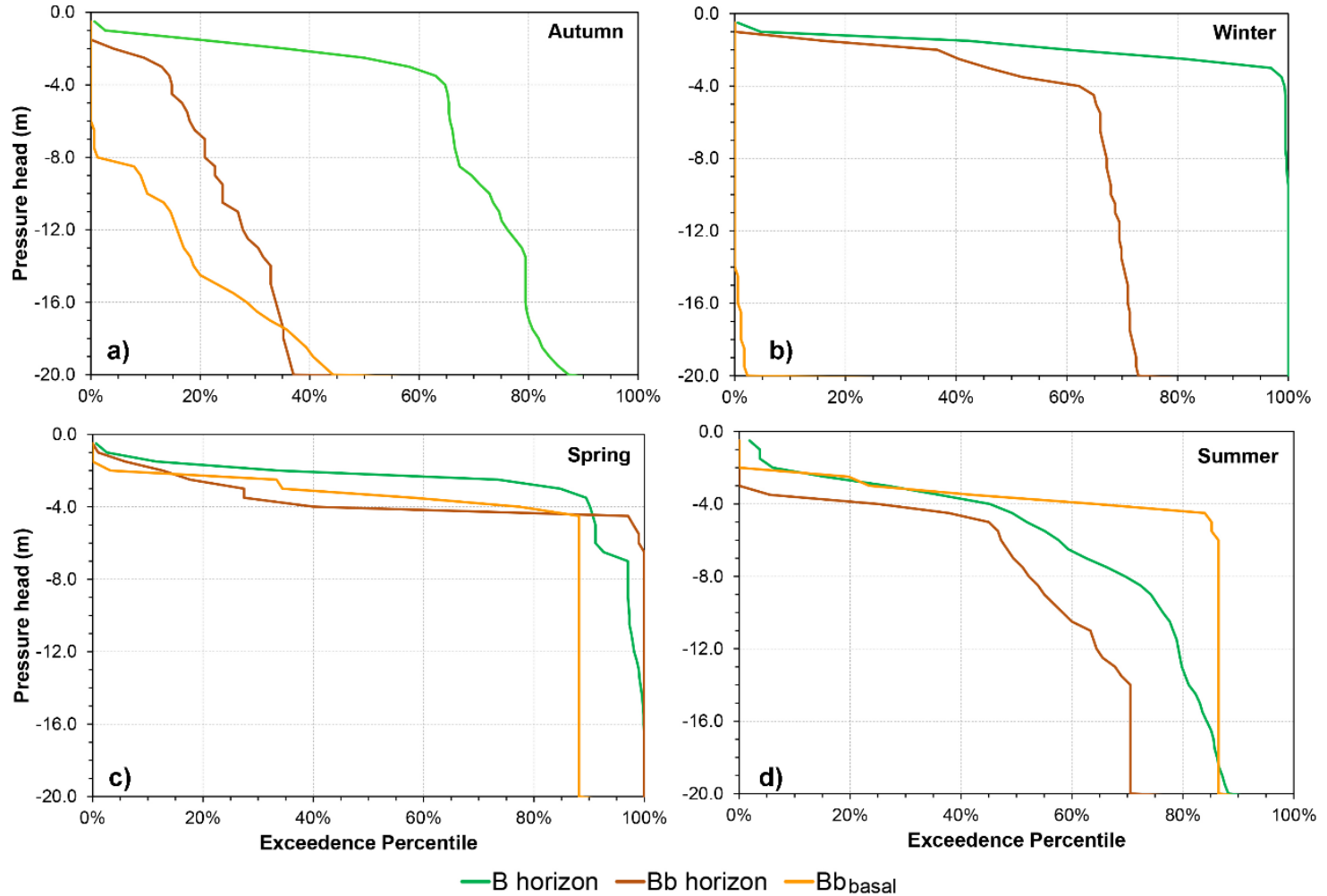

Figure 7. Seasonal duration curves (DCs) of soil pressure head data for $\mathrm{B}, \mathrm{Bb}$, and $\mathrm{Bb}_{\text {basal }}$ soil horizons related to: autumn (a), winter (b), spring (c), and summer (d), modified from [38].

Considering the results of the hydrological monitoring and the related frequency analyses, two levels of soil pressure head, chosen as representative of the wet period spanning across winter and partly spring, and the dry one including summer and early autumn, were identified and used as antecedent hydrological conditions for a coupled hydrological and slope stability model. These two opposite settings were considered as significant for dealing with uncertainties in assessing rainfall thresholds triggering debris flows [5] given by undefined antecedent hydrological conditions [40]. The first was identified from the winter soil pressure head values measured for the shallower $\mathrm{B}$ horizon, ranging within the whole volcaniclastic soil mantle from $-0.5 \mathrm{~m}$ to $-1.0 \mathrm{~m}$. These values were evaluated as being consistent with those measured for the same season by other hydrological monitoring campaigns on ash-fall pyroclastic soils [47-49]. Moreover, they were considered as representative of a very wet hydrological status occurring after relevant rainfall events and conceived as indicating a high predisposition to debris flow triggering under heavy rainfall events and then potentially working as a landslide alert threshold. Similarly, typical dry conditions occurring between summer and early autumn were identified approximately corresponding to an exceeding frequency of $50 \%$ (Figure $7 \mathrm{~d}$ ) with values ranging between -5.0 and $-8.0 \mathrm{~m}$.

\subsection{Hydrological and Slope Stability Modeling}

Hydrological modeling and infinite slope stability analyses allowed us to determine the critical durations of rainfall to slope failure with given constant intensities and opposite (winter and summer) antecedent hydrological conditions (Figure 8), leading to the reconstruction of deterministic intensity-duration thresholds (Figure 9 and Table 5). 


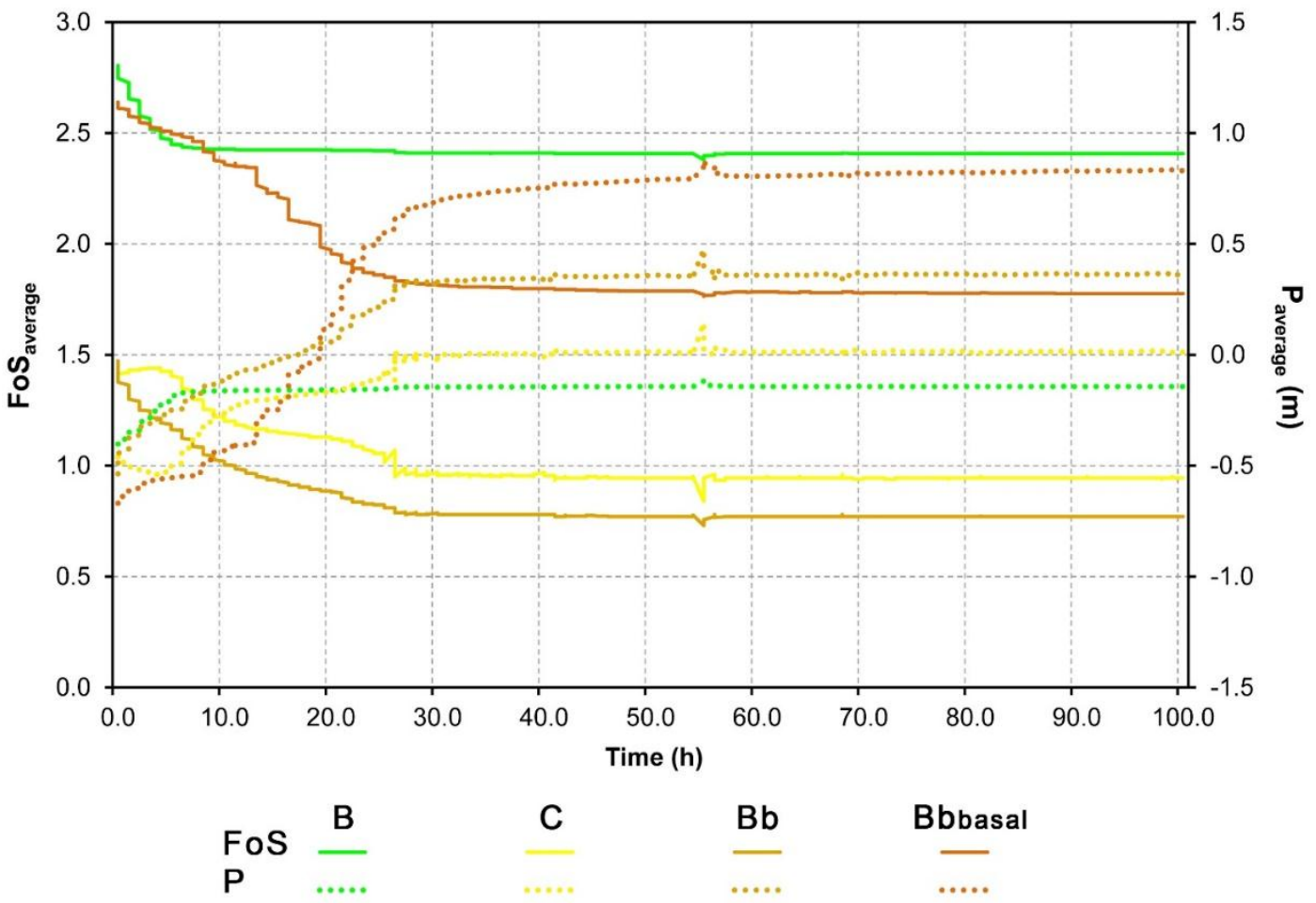

Figure 8. Example of the factor of safety (FoS) and soil pressure head $(\mathrm{P})$ time series simulated for each soil horizon for the $40^{\circ}$ slope model of the Sarno Mountains under a constant rainfall intensity of $20 \mathrm{~mm} / \mathrm{h}$ and winter antecedent hydrological conditions.
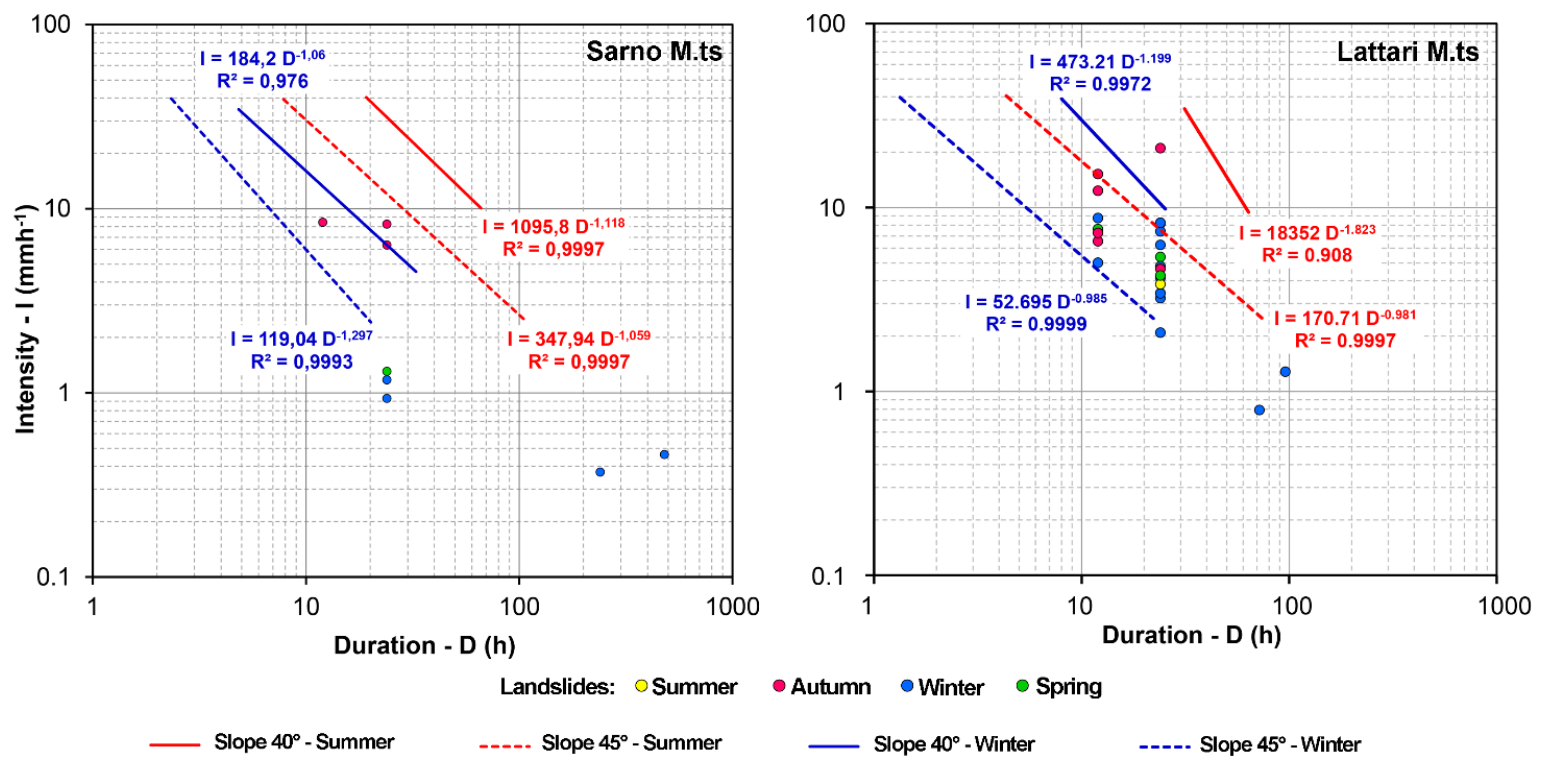

Figure 9. Intensity-duration rainfall thresholds reconstructed for $35^{\circ}, 40^{\circ}$, and $45^{\circ}$ slope models of the Sarno (a) and Lattari Moutains (b) and winter and summer antecedent hydrological conditions. Colored circles represent I-D rainfall conditions recorded for debris flow events known by chronicles and scientific literature, seasonally divided [50-52]. 
Table 5. Duration (hours) of rainfall events with constant intensity $(2.5,5,10,20$, and $40 \mathrm{~mm} / \mathrm{h})$ to slope failure for $35^{\circ}, 40^{\circ}$, and $45^{\circ}$ slope models of the Sarno and Lattari Mountains related to winter and summer antecedent hydrological conditions, respectively.

\begin{tabular}{|c|c|c|c|c|c|c|}
\hline \multicolumn{7}{|c|}{ Winter Antecedent Hydrological Conditions } \\
\hline & \multicolumn{3}{|c|}{ Sarno Mountains } & \multicolumn{3}{|c|}{ Lattari Mountains } \\
\hline Slope Angle & $35^{\circ}$ & $40^{\circ}$ & $45^{\circ}$ & $35^{\circ}$ & $40^{\circ}$ & $45^{\circ}$ \\
\hline $\mathrm{I}(\mathrm{mm} / \mathrm{h})$ & \multicolumn{6}{|c|}{ Duration to Failure (h) } \\
\hline 2.5 & - & - & 20.2 & - & - & 22.2 \\
\hline 5 & - & 32.8 & 11.2 & - & - & 11.0 \\
\hline 10 & - & 13.8 & 6.7 & - & 25.3 & 5.3 \\
\hline 20 & - & 7.3 & 4.0 & - & 13.5 & 2.7 \\
\hline 40 & - & 4.8 & 2.3 & - & 8.0 & 1.3 \\
\hline \multicolumn{7}{|c|}{ Summer Antecedent Hydrological Conditions } \\
\hline & \multicolumn{3}{|c|}{ Sarno Mountains } & \multicolumn{3}{|c|}{ Lattari Mountains } \\
\hline Slope Angle & $35^{\circ}$ & $40^{\circ}$ & $45^{\circ}$ & $35^{\circ}$ & $40^{\circ}$ & $45^{\circ}$ \\
\hline $\mathrm{I}(\mathrm{mm} / \mathrm{h})$ & \multicolumn{6}{|c|}{ Duration to Failure (h) } \\
\hline 2.5 & - & - & 107.8 & - & - & 74.8 \\
\hline 5 & - & - & 54.3 & - & - & 35.8 \\
\hline 10 & - & 66.2 & 27.8 & - & 63.5 & 17.8 \\
\hline 20 & - & 36.3 & 14.8 & - & 37.2 & 9.2 \\
\hline 40 & - & 19.2 & 7.8 & - & 31.8 & 4.3 \\
\hline
\end{tabular}

The outcomes allowed us to focus on some important points. The first was that the hydrological response and instability of the pyroclastic fall soil mantle were closely linked to the variation of slope angle due to controlling the reduction of thickness and the decrease of the duration of rainfall events determining the landslide triggering (Table 5) as well as the occurrence of greater driving forces. The other is the important role played by the antecedent hydrological conditions. In fact, if the summer antecedent hydrological condition was considered, the I-D threshold shifted towards a major amount of rainfall (Figure 9) up to extreme rainfall, which was very unlikely to occur.

Another important point regarded the difference between the I-D thresholds determined for the three slope angle values considered in the modeling phase. For the $45^{\circ}$ slope models and winter initial hydrological conditions, the difference between the I-D thresholds of the Sarno and Lattari Mountains was limited to a duration range of less than two hours. Instead, if considering the summer hydrological conditions for the same slope angle and rainfall intensity, the difference was more enhanced. For the $40^{\circ}$ slope model, the I-D thresholds between the two studied areas were found to be relevantly different, very likely due to the different thickness and stratigraphic settings of the pyroclastic fall soil mantle (Table 5). Moreover, neither for the $35^{\circ}$ slope models and all the tested rainfall intensities, nor the rainfall intensity of $2.5 \mathrm{~mm} / \mathrm{h}$ and $40^{\circ}$ slope models, were the slope failures estimated. This observation was supported by the experience that debris flows involving pyroclastic fall soils are rarely initiated in morphological conditions with a slope angle value of $35^{\circ}$ [44].

Finally, the simulated pressure head values demonstrated the possible occurrence of transitory saturated conditions leading to a saturated throughflow that especially occurred in the case of the winter antecedent hydrological conditions (Figure 8).

The comparison between the I-D rainfall thresholds with rainfall associated with debris flow events known by the chronicles and reported in scientific papers [50-52] and classified on the basis of seasonality showed that these events were consistently included within the winter and summer thresholds (Figure 9). In particular, points representative of these events were below the I-D rainfall thresholds for the winter and summer antecedent hydrological conditions identified by a slope angle of $40^{\circ}$, but in line with the case of slope angle of $45^{\circ}$. These observations were considered as useful for 
a basic validation of the I-D rainfall thresholds even if the reliability of this comparison is considered to be limited by the unknown morphological conditions of the source areas and uncertainties affecting rainfall recordings, often taken by rain gauge stations located at great altitudinal and planimetric distances from the debris flow initiation areas.

\section{Discussion}

This research focused on the comprehension of the seasonal hydrological response of the pyroclastic fall soil coverings through a six-year hydrological monitoring of soil pressure head, allowing us to advance the results obtained by preceding studies [53-56]. The outcomes of the hydrological soil monitoring were used to set up the seasonal antecedent hydrological conditions of coupled hydrological and slope stability modeling, which was performed on the physical slope models and considered rainfall events with a constant rainfall intensity (event-based modeling). These analyses led to the estimation of the deterministic intensity-duration rainfall thresholds, which could be used for assessing and managing hazards to debris flow initiation by setting a reliable early warning system in the mountainous and hilly areas of the Campania region (Southern Italy) mantled by air-fallen volcanic ashes.

In the monitoring period, the highest values of pressure head measured were during the wet period. These data matched well with the others measured in several experimental monitoring sites in pyroclastic fall soil mantled slopes of the Campania region [57-64]. According to the results of these preceding studies, saturation conditions were never observed, even in the shallower B horizon where maximum soil pressure head values close to $-0.5 \mathrm{~m}$ were measured after intense rainfall events. Moreover, in the wet period, the soil pressure head values ranged roughly in a limited interval due to an approximate equilibrium between infiltration and water losses towards the atmosphere, due to being sustained by a reduced evapotranspiration demand during the dormant stage of the deciduous chestnut forest. Then, starting from late spring until early autumn, a sudden decline in the soil pressure head values was observed due to the rapid increase of the evapotranspiration demand. The latter was fostered by the growth of leaf coverage in the activity period of the deciduous chestnut forest. Soil pressure head occurring in this dry period reached values far lower than those measured by preceding studies [58-64], which were based only on the use of tensiometers, and consequently limited to $-8.0 \mathrm{~m}$. Specifically, owing to the increased evapotranspiration demand and lower precipitation, soil pressure head exceeded the functioning limit of the Watermark sensor $(\mathrm{h}<-20.4 \mathrm{~m})$ with relevant frequencies (Figures 6 and 7), reaching its lowest peaks down to $-152.2 \mathrm{~m}$ (Table 4), measured only by the MPS-2 sensors. These results revealed a seasonal hydrological response of the pyroclastic fall soil mantled slopes of the Campania region characterized unexpectedly by very wide dynamics not capturable only by tensiometers.

The selective monitoring of soil pressure head for each soil horizon and, namely at different depths, allowed us to advance the comprehension of the hydrological behavior of the pyroclastic fall soil mantle, which resulted in being more complex than expected. In fact, the hydrological response appeared to not occur simultaneously at all depths, but was remarkably delayed from the shallowest $B$ horizon to the deepest $\mathrm{Bb}_{\text {basal }}$ one so much that determining, at the same time, opposite conditions between the shallower and deeper soil horizons.

Another important outcome of the monitoring activity was the involvement of the whole volcaniclastic soil cover in the seasonal hydrological response, even with a total thickness of about $4.5 \mathrm{~m}$ as in the case of the monitoring site. This observation allowed the understanding that the evapotranspiration zone was more extended than the shallower B soil horizon due to the action of deeper root apparatuses as well as the effects of the upward vertical hydraulic gradient $[49,63]$. From this finding, it can be derived that a similar hydrological behavior could occur in other slope geomorphological conditions of the mountain ranges surrounding the volcanic centers of the Campania region, with the same or lower thicknesses of pyroclastic fall soil deposits. 
From the frequency analyses of the soil pressure head time series, it was assessed that wetter hydrological conditions favoring slope instability occurred during winter and spring when more than $50 \%$ of the soil pressure head values ranged between $-0.5 \mathrm{~m}$ and $-2.0 \mathrm{~m}$. For instance, in these conditions, infiltration following heavy rainfall events could determine the rise of unsaturated hydraulic conductivity in the shallower soil horizons promoting unsaturated throughflow within the volcaniclastic soil cover, and the formation of near-saturated or saturated wedges at downslope hydrogeological discontinuities [37] such as those represented by the local reduction of thickness or pinching out of soil horizons, occurring as the slope angle increases beyond $35^{\circ}$ [39]. Opposingly, drier hydrological conditions of the pyroclastic fall soil cover existing during summer, prevented slope instability even during heavy rainstorms.

Such a seasonal slope hydrological behavior exerts a fundamental role on predisposing or preventing slope instability in the case of a single rainfall event. Consequently, these results pointed out the important role of antecedent hydrological conditions [40] and allowed us to comprehend the severe uncertainty given by not considering them in estimating the hydrological thresholds, aimed at setting up an early warning system.

The I-D thresholds estimated were set on the basis of coupled hydrological and slope stability modeling applied to physical models of initial debris slides of representative slope areas of the Sarno Mountains (May 1998) [39]. Other attempts of modeling the hydrological regime of pyroclastic fall soil coverings during heavy rainstorms and coupling it with slope stability analysis by a physically based approach have also been made in other studies $[47,58,59,61,65]$. To progress these results, an advance of the I-D rainfall thresholds estimation was proposed in this research, by applying coupled hydrological and slope stability modeling to the physical slope models of the Sarno and Lattari Mountains, reconstructed for slope angles of $35^{\circ}, 40^{\circ}$, and $45^{\circ}$, and considering the seasonal antecedent hydrological conditions derived by hydrological monitoring. These physical models reproduced the thickness and stratigraphic settings that typically exist in the Sarno and Lattari Mountains [42,43] in the slope angle interval where debris flows initiate most frequently [40]. Therefore, these models can be conceived as an attempt to generalize the physical conditions, and even to expand them at the distributed scale, for assessing I-D rainfall thresholds and linking them to different morphological and antecedent soil hydrological conditions. The results obtained revealed a good match of the I-D rainfall conditions with the not numerous landslide events known by the chronicles and scientific papers [51,52].

Furthermore, the control of the antecedent hydrological conditions appeared to be very relevant because if the dry season was considered, the duration of critical rainfall increased remarkably. This result confirmed what derived from the experience about the most frequent occurrence of debris flows, taking place mostly at the end of winter or beginning of spring (e.g., high magnitude event of the Sarno Mountains on 5-6 May 1998). In addition, the debris flows also occurred frequently during heavy early-autumnal rainstorms in mountainous areas with a thinner pyroclastic fall soil mantle such as for the events of the Lattari Mountains.

Finally, based on the outcomes of this research and the preceding ones [38], it was possible to depict the pyroclastic fall coverings as characterized by distinctive features in comparison to other autochthonous ones (e.g., saprolitic or colluvial), regarding their hydrological behavior and control on rainfall-induced triggering of shallow landslides. The first distinctive character is given by the unsaturated hydrological properties of volcanic ashes, which, due to their high inter- and intra-particle porosity as well as specific surface area [66], are characterized by a high water retention capacity, greater than that of other non-pyroclastic soils of the same grain size. Such a feature, combined with the outcomes of soil hydrological monitoring, which revealed the involvement of the whole pyroclastic fall soil covering in the seasonal hydrological dynamics (up to a depth of $4.5 \mathrm{~m}$ ), opens new perspectives in the comprehension of the hydrological behavior of volcaniclastic soil mantle. 
In this regard, the measurements of soil pressure head revealed unexpected seasonal low values, even deeper than the B horizon, which exceeded any of the lowest values recorded in other autochthonous soil coverings [67].

From the preceding findings, at the seasonal time scale, the results of the available water (AW) for evapotranspiration, comprised of the field capacity (FC) and the permanent wilting point (PWP), were controlled by the thickness of the pyroclastic fall soil covering. This outcome allowed us to hypothesize a hydro-geomorphological model where the slope angle controls both the thickness of the pyroclastic fall soil covering and its seasonal [38] and event-based hydrological dynamics, leading to a more enhanced hydrological response for steeper slope sectors covered by thinner volcaniclastic soil coverings. In these slope sectors, at the seasonal time-scale, the soil pressure head values fluctuated across a wider range due to the lower AWC, therefore reaching a near saturation condition more frequently during winter and spring, leading to easier slope instability conditions under the occurrence of a single rainfall event with not extreme I-D characteristics.

Considering the set of these features, pyroclastic fall soil coverings can be understood as being very different and peculiar in comparison to other autochthonous ones (e.g., saprolitic and colluvial) regarding hydrological behavior and its control on the rainfall-induced triggering of debris flows.

\section{Conclusions}

Assessing hazards related to rainfall-induced debris flows is a challenging task for the management of urbanized areas and deserves careful estimations aimed at setting up reliable early warning systems. Therefore, efforts must be made for reducing the uncertainties related to the assessment of the thresholds of the hydrological conditions leading to debris flow initiation and to minimize their dangerous misestimations.

In this paper, an approach for estimating the I-D rainfall thresholds triggering debris flows in the pyroclastic fall soil mantled slopes of the Campania region (Southern Italy) was proposed. It can be conceived as an adaptable tool for assessing hazards to debris flow initiation by taking into account the compound probability derived by the probabilities of given antecedent hydrological conditions and rainfall events with given intensity and duration [68], and by also considering the effects of different morphological conditions. Therefore, the obtained results can be conceived as potentially reducing the uncertainties related to the assessment of hydrological thresholds based only on the empirical analyses of rainfall events recorded for past landslide occurrences.

The results achieved in this research allowed us to advance the understanding of the hydrological response of the pyroclastic fall soil mantled slopes of the Campania region (Southern Italy) on triggering debris flows. Among the principal results was the understanding that, mainly depending on the thicknesses and stratigraphic settings, the pyroclastic fall soil coverings had a fundamental control on the timing and intensity of the hydrological processes leading to debris flow initiation. Moreover, another principal aspect that characterized these volcanic soil coverings was the high water-retention capacity, which allowed a high storage of soil water [38]. This feature, combined with a typical Mediterranean climate, fosters the growth of deciduous chestnut forests, determining a high seasonal evapotranspiration demand and variability of soil pressure head values. Therefore, the same rainfall event resulted in having different chances to trigger shallow landslides depending first on the antecedent hydrological conditions [40], then on the seasonal effect.

In conclusion, the approach proposed for estimating the I-D thresholds can be considered as an alternative to empirically-based ones and is useful for considering different hazard levels related to seasonality, which is potentially not only limited to pyroclastic fall soil coverings.

Author Contributions: Methodology, Software, Validation, Formal Analysis, Investigation, Resources, Data Curation, Writing-Original Draft Preparation, Visualization: Francesco Fusco, Rita Tufano and Delia Cusano. Conceptualization, Writing-review \& Editing, Project Administration, Funding Acquisition and Supervision: Pantaleone De Vita. 
Funding: This research was funded by the Governmental Commissariat for the hydrological emergency in the Campania region (Act No. 1902 of 25 September 2001) and the Ph.D. Program (2014-2018) of the Dipartimento di Scienze della Terra, dell'Ambiente e delle Risorse, University of Naples Federico II.

Acknowledgments: We thank Enrico di Clemente for helped us in organizing the field and laboratory data.

Conflicts of Interest: The authors declare no conflict of interest.

\section{References}

1. Lagomarsimo, D.; Segoni, S.; Fanti, R.; Catani, F. Updating and tuning a regional-scale landslide early warning system. Landslides 2013, 10,91-97. [CrossRef]

2. Guzzetti, F.; Peruccacci, S.; Rossi, M.; Stark, C.P. Rainfall thresholds for the initiation of landslides in central and southern Europe. Meteorol. Atmos. Phys. 2007, 98, 239-267. [CrossRef]

3. Caine, N. The rainfall intensity-duration control of shallow landslides and debris flows. Geogr. Ann. 1980, 62, $23-27$.

4. Crozier, M.J.; Eyles, R.J. Assessing the probability of rapid mass movement. In Proceedings of the 3rd Australia New Zealand Conference on Geomechanics, Wellington, New Zealand, 12-16 May 1980; Volume 6, pp. 2.47-2.51.

5. Nikolopoulos, E.I.; Crema, S.; Marchi, L.; Marra, F.; Guzzetti, F.; Borga, M. Impact of uncertainty in rainfall estimation on the identification of rainfall thresholds for debris flow occurrence. Geomorphology 2014, 221, 286-297. [CrossRef]

6. Mirus, B.B.; Nimmo, J.R. Balancing practicality and hydrologic realism: a parsimonious approach for simulating rapid groundwater recharge via unsaturated-zone preferential flow. Water Resour. Res. 2013, 49, 1458-1465. [CrossRef]

7. Godt, J.W.; Schulz, W.H.; Baum, R.L.; Savage, W.Z. Modeling rainfall conditions for shallow landsliding in Seattle, Washington. In Landslides and Engineering Geology of the Seattle, Washington, Area; Baum, R.L., Godt, J.W., Highland, L.M., Eds.; Geological Society of America Reviews in Engineering Geology; Geological Society of America: Boulder, CO, USA, 2008; Volume 20, pp. 137-152.

8. Peres, D.J.; Cancelliere, A. Derivation and evaluation of landslide-triggering thresholds by a Monte Carlo approach. Hydrol. Earth Syst. Sci. 2014, 18, 4913-4931. [CrossRef]

9. Guadagno, F.M.; Revellino, P.; Grelle, G. The 1998 Sarno landslides: conflicting interpretations of a natural event. In Italian Journal of Engineering Geology and Environment, Proceedings of the 5th International Conference on Debris-Flow Hazards "Mitigation, Mechanics, Prediction and Assessment", Rome, Italy, 14 June 2011; Genevois, R., Hamilton, D.L., Prestininzi, A., Eds.; Sapienza Università Editrice University Press: Rome, Italy, 2011; pp. 71-81. [CrossRef]

10. GEO-Geotechnical Engineering Office, Hong Kong Government; Government of the Hong Kong Special Administrative Region; Geotechnical Engineering Office. Landslides and Boulder Falls from Natural Terrain: Interim Risk Guideline. GEO Report No. 75; Government Publications Centre: Hong Kong, China, 1998.

11. HSE-United Kingdom Health and Safety Executive. Reducing Risk, Protecting People, HSE Decision-Making Process; HM Stationery Office: London, UK, 2001.

12. Campbell, R. Soil Slips, Debris Flows and Rainstorms in the Santa Monica Mountains and Vicinity, Southern California. In USGS Professional Paper; U.S. Geological Survey: Washington, DC, USA, 1975; Volume 851, p. 51.

13. Montgomery, D.R.; Dietrich, W.E.; Torres, R.; Anderson, S.P.; Heffner, J.T.; Loague, K. Hydrologic response of a steep, unchanneled valley to natural and applied rainfall. Water Resour. Res. 1997, 33, 91-109. [CrossRef]

14. Selby, M.J. Hillslope Materials and Processes, 2nd ed.; Oxford University Press: Oxford, UK, 2000; p. 451.

15. Allocca, V.; Manna, F.; De Vita, P. Estimating annual groundwater recharge coefficient for karst aquifers of the southern Apennines (Italy) 2014. Hydrol. Earth Syst. Sci. 2014, 18, 803-817. [CrossRef]

16. Allocca, V.; De Vita, P.; Manna, F.; Nimmo, J.R. Groundwater recharge assessment at local and episodic scale in a soil mantled perched karst aquifer in southern Italy. J. Hydrol. 2015, 529, 843-853. [CrossRef]

17. D'Argenio, B.; Pescatore, T.; Scandone, P. Schema geologico dell'Appennino Meridionale (Campania e Lucania). In Proceedings of the meeting "Moderne vedute sulla geologia dell'Appennino", Rome, Italy, 16-18 February 1972; Quaderni Accademia Nazionale dei Lincei: Rome, Italy, 1973; Volume 183, pp. 49-72. 
18. Mostardini, F.; Merlini, S. Appennino centro meridionale. Sezioni geologiche e proposta di modello strutturale. Mem. Soc. Geol. Ital. 1986, 35, 177-202.

19. Patacca, E.; Scandone, P. Geological interpretation of the CROP-04 seismic line (Southern Apennines, Italy). Boll. Soc. Geol. Ital. 2007, 7, 297-315.

20. USDA. Keys to Soil Taxonomy, 12th ed.; United States Department of Agriculture Natural Resources Conservation Service: Washington, DC, USA, 2014; p. 372.

21. Schmidt, R. Descriptive nomenclature and classification of pyroclastic deposits and fragments: Recommendations of the I.U.G.S. Subcommission on the Systematics of Igneous Rocks. Geology 1981, 9, 41-43. [CrossRef]

22. Rolandi, G.; Petrosino, P.; Mc Geehin, J. The interplinian activity at Somma-Vesuvius in the last 3500 years. J. Volcanol. Geotherm. Res. 1998, 82, 19-52. [CrossRef]

23. Rolandi, G.; Mastrolorenzo, G.; Barrella, A.M.; Borrelli, A. The Avellino Plinian eruption of Somma-Vesuvius (3760 y B.P.): the progressive evolution from magmatic to hydromagmatic style. J. Volcanol. Geotherm. Res. 1993, 58, 67-88. [CrossRef]

24. Rolandi, G.; Maraffi, S.; Petrosino, P.; Lirer, L. The Ottaviano eruption of Somma-Vesuvius (8000 y B.P.): A magmatic alternating fall and flow forming eruption. J. Volcanol. Geotherm. Res. 1993, 58, 43-65. [CrossRef]

25. Lirer, L.; Pescatore, T.; Booth, B.; Walker, J.P.L. Two Plinian pumice-fall deposits from Somma-Vesuvius. Geol. Soc. Am. Bull. 1973, 84, 759-772. [CrossRef]

26. Cole, P.D.; Scarpati, C. The 1944 eruption of Vesuvius, Italy: Combining contemporary accounts and field studies for a new volcanological reconstruction. Geol. Mag. 2010, 147, 391-415. [CrossRef]

27. Varnes, D.J. Slope movement types and processes. In Landslides: Analysis and Control Special Report 176; Schuster, R.L., Krizek, R.J., Eds.; Transportation and Road Research Board, National Academy of Science: Washington, DC, USA, 1978; pp. 11-33.

28. Cruden, D.M.; Varnes, D.J.; Turner, A.K.; Schuster, R.L. Landslide Types and Processes. In Landslides, Investigation and Mitigation; Transportation Research Board, US National Research Council: Washington, DC, USA, 1996; Volume 247, pp. 36-75.

29. Hungr, O.; Leroueil, S.; Picarelli, L. The Varnes classification of landslide types, an updated. Landslides 2014, 11, 167-194. [CrossRef]

30. Jakob, M.; Hungr, O. Debris-Flow Hazards and Related Phenomena; Springer: Berlin/Heidelberg, Germany, 2005; Volume 739, ISBN 978-3-540-27129-1.

31. Celico, P.; Guadagno, F.M.; Vallario, A. Proposta di un modello interpretativo per lo studio delle frane nei terreni piroclastici. Geol. Appl. Idrogeol. 1986, 21, 173-193.

32. Cascini, L.; Cuomo, S.; Guida, D. Typical source areas of May 1998 flow-like mass movements in the Campania region, Southern Italy. Eng. Geol. 2008, 96, 107-125. [CrossRef]

33. De Vita, P.; Nappi, M. Regional distribution of ash-fall pyroclastic soils for landslide susceptibility assessment. In Landslide Science and Practice; Margottini, C., Canuti, P., Sassa, K., Eds.; Springer: Berlin/Heidelberg, Germany, 2013; pp. 103-109.

34. De Vita, P.; Agrello, D.; Ambrosino, F. Landslide susceptibility assessment in ashfall pyroclastic deposits surrounding Mount Somma-Vesuvius. Application of geophysical surveys for soil thickness mapping. J. Appl. Geophys. 2006, 59, 126-139. [CrossRef]

35. Del Soldato, M.; Pazzi, V.; Segoni, S.; De Vita, P.; Tofani, V.; Moretti, S. Spatial modeling of pyroclastic cover deposit thickness (Depth to bedrock) in peri-volcanic area of Campania (southern Italy). Earth Surf. Process. Landf. 2018, 43, 1757-1767. [CrossRef]

36. De Vita, P.; Celico, P.; Siniscalchi, M.; Panza, R. Distribution, hydrogeological features and landslide hazard of pyroclastic soils on carbonate slopes in the area surrounding Mount Somma-Vesuvius. Ital. J. Eng. Geol. Environ. 2006, 1, 1-24.

37. Reid, M.E.; Nielsen, H.J.P.; Dreiss, S.J. Hydrologic factors triggering a shallow hillslope failure. Bull. Assoc. Eng. Geol. 1988, 25, 349-362. [CrossRef]

38. Fusco, F.; Allocca, V.; De Vita, P. Hydro-geomorphological modeling of ash-fall pyroclastic soils for debris flow initiation and groundwater recharge in Campania (southern Italy). Catena 2017, 158, 235-249. [CrossRef]

39. De Vita, P.; Napolitano, E.; Godt, J.W.; Baum, R. Deterministic estimation of hydrological thresholds for shallow landslide initiation and slope stability models: case study from the Somma-Vesuvius area of southern Italy. Landslides 2013, 10, 713-728. [CrossRef] 
40. Napolitano, E.; Fusco, F.; Baum, R.L.; Godt, J.W.; De Vita, P. Effect of antecedent hydrological conditions on rainfall triggering of debris flows in ash-fall pyroclastic mantled slopes of Campania (southern Italy). Landslides 2016, 13, 967-983. [CrossRef]

41. Helsel, D.R.; Hirsch, R.M. Statistical Methods in Water Resources; Techniques of Water-Resources; Investigations of the United States Geological Survey: Reston, VA, USA, 2002; Volume 4, p. 510.

42. Tufano, R.; Fusco, F.; De Vita, P. Spatial modeling of ash-fall pyroclastic deposits for the assessment of rainfall thresholds triggering debris flows in the Sarno and Lattari mountains (Campania, southern Italy). Rend. Online Soc. Geol. Ital. 2016, 41, 210-213. [CrossRef]

43. De Vita, P.; Fusco, F.; Napolitano, E.; Tufano, R. Physically-Based Models for Estimating Rainfall Triggering Debris Flows in Campania (southern Italy). In Advancing Culture of Living with Landslides, Diversity of Landslide Forms; Mikoš, M., Arbanas, Z., Yin, Y., Sassa, K., Eds.; Springer International Publishing AG: Basel, Switzerland, 2017; Volume 4, pp. 289-297. [CrossRef]

44. De Riso, R.; Budetta, P.; Calcaterra, D.; Santo, A. Le colate rapide in terreni piroclastici del territorio campano. In Proceedings of the Atti della conferenza su Previsione e prevenzione di movimenti franosi rapidi, Trento, Italy, 17-19 June 1999; Peila, D., Ed.; GEAM. pp. 133-150.

45. Hsieh, P.A.; Wingle, W.; Healy, R.W. VS2DI-A graphical software package for simulating fluid flow and solute or energy transport in variably saturated porous media. In Water-Resources Investigations Report 99-4130; U.S. Geological Survey: Reston, WV, USA, 2000. [CrossRef]

46. Lu, N.; Likos, W.J. Unsaturated Soil Mechanics; Wiley: Hoboken, NJ, USA, 2004; p. 556, ISBN 978-0-471-44731-3.

47. Papa, M.N.; Medina, V.; Ciervo, E.; Bateman, A. Derivation of critical rainfall thresholds for shallow landslides as a tool for debris flow early warning systems. Hydrol. Earth Syst. Sci. 2013, 17, 4095-4107. [CrossRef]

48. Sorbino, G. Numerical modeling of soil suction measurements in pyroclastic soils. In International Symposium "Advanced Experimental Unsaturated Soil Mechanics"; Cui, Y.J., Tarantino, A., Romero, E., Eds.; Taylor and Francis Group: London, UK, 2005; pp. 541-547.

49. Urciuoli, G.; Pirone, M.; Comegna, L.; Picarelli, L. Long-term investigations on the pore pressure regime in saturated and unsaturated sloping soils. Eng. Geol. 2016, 212, 98-119. [CrossRef]

50. Del Prete, M.; Guadagno, F.M.; Hawkins, A.B. Preliminary report on the landslides of 5 May 1998, Campania, southern Italy. Bull. Eng. Geol. Environ. 1998, 57, 113-129. [CrossRef]

51. Calcaterra, D.; Parise, M.; Palma, B.; Pelella, L. The influence of meteoric events in triggering shallow landslides in pyroclastic deposits of Campania, Italy. In Landslides in Research, Theory and Practice, Proceedings of the 8th International Symposium on Landslides, Cardiff, UK, 26-30 June 2000; Bromhead, E., Dixon, N., Ibsen, M.L., Eds.; Thomas Telford Publishing: London, UK, 2000; pp. 209-214.

52. De Vita, P.; Piscopo, P. Influences of hydrological and hydrogeological conditions on debris flows in peri-Vesuvian hillslopes. Nat. Hazards Earth Syst. Sci. 2002, 2, 1-9. [CrossRef]

53. Ebel, B.A.; Loague, K. Rapid simulated hydrologic response within the variably saturated near surface. Hydrol. Process. 2008, 22, 464-471. [CrossRef]

54. De Vita, P.; Di Maio, R.; Piegari, E. A study of the correlation between electrical resistivity and matric suction for unsaturated ash-fall pyroclastic soils in the Campania region (southern Italy). Environ. Earth Sci. 2012, 67, 787-798. [CrossRef]

55. Fusco, F.; De Vita, P.; Napolitano, E.; Allocca, V.; Manna, F. Monitoring the soil suction regime of landslide-prone ash-fall pyroclastic deposits covering slopes in the Sarno area (Campania—southern Italy). Rend. Online Soc. Geol. Ital. 2013, 24, 146-148.

56. Fusco, F.; De Vita, P. Hydrological behavior of ash-fall pyroclastic soil mantled slopes of the Sarno Mountains (Campania-southern Italy). Rend. Online Soc. Geol. Ital. 2015, 35, 148-151. [CrossRef]

57. Fusco, F.; De Vita, P. Hydrological Monitoring of Ash-Fall Pyroclastic Soil Mantled Slopes in Campania (southern Italy). In Advancing Culture of Living with Landslides, Advances in Landslide Technology; Mikoš, M., Arbanas, Z., Yin, Y., Sassa, K., Eds.; Springer: Cham, Switzerland, 2017; Volume 3, pp. 349-356. [CrossRef]

58. Cascini, L.; Sorbino, G.; Cuomo, S.; Ferlisi, S. Seasonal effects of rainfall on the shallow pyroclastic deposits of the Campania region (southern Italy). Landslides 2014, 11, 779-792. [CrossRef]

59. Damiano, E.; Olivares, L.; Picarelli, L. Steep-slope monitoring in unsaturated pyroclastic soils. Eng. Geol. 2012, 137-138, 1-12. [CrossRef] 
60. Greco, R.; Comegna, L.; Damiano, E.; Guida, A.; Olivares, L.; Picarelli, L. Hydrological modeling of a slope covered with shallow pyroclastic deposits from field monitoring data. Hydrol. Earth Syst. Sci. 2013, 17, 4001-4013. [CrossRef]

61. Comegna, L.; Damiano, E.; Greco, R.; Guida, A.; Olivares, L.; Picarelli, L. Effects of the vegetation on the hydrological behavior of a loose pyroclastic deposit. Procedia Environ. Sci. 2013, 19, 922-931. [CrossRef]

62. Pagano, L.; Picarelli, L.; Rianna, G.; Urciuoli, G. A simple numerical procedure for timely prediction of precipitation-induced landslides in unsaturated pyroclastic soils. Landslides 2010, 7, 273-289. [CrossRef]

63. Papa, R.; Pirone, M.; Nicotera, M.V.; Urciuoli, G. Seasonal groundwater regime in an unsaturated pyroclastic slope. Géotechnique 2013, 63, 420-426. [CrossRef]

64. Comegna, L.; Damiano, E.; Greco, R.; Guida, A.; Olivares, L.; Picarelli, L. Field hydrological monitoring of a sloping shallow pyroclastic deposit. Can. Geotech. J. 2016, 53, 1125-1137. [CrossRef]

65. Crosta, G.B.; Dal Negro, P. Observations and modeling of soil slip-debris flow initiation processes in pyroclastic deposits: the Sarno 1998 event. Nat. Hazards Earth Syst. Sci. 2003, 3, 53-69. [CrossRef]

66. Esposito, L.; Guadagno, F.M. Some special geotechnical properties of pumice deposits. Bull. Eng. Geol. Environ. 1998, 57, 41-50. [CrossRef]

67. Leung, A.K.; Ng, C.W.W. Seasonal movement and groundwater flow mechanism in an unsaturated saprolitic hillslope. Landslides 2013, 10, 455-467. [CrossRef]

68. Glade, T.; Crozier, M.; Smith, P. Applying probability determination to refine landslide-triggering rainfall thresholds using an empirical "antecedent daily rainfall model". Pure Appl. Geophys. 2000, 157, 1059-1079. [CrossRef]

(C) 2018 by the authors. Licensee MDPI, Basel, Switzerland. This article is an open access article distributed under the terms and conditions of the Creative Commons Attribution (CC BY) license (http://creativecommons.org/licenses/by/4.0/). 